\title{
Models of ice melting and edifice growth at the onset of subglacial basaltic eruptions
}

\author{
Hugh Tuffen ${ }^{1,2}$ \\ Received 22 May 2006; revised 13 September 2006; accepted 25 October 2006; published 13 March 2007.
}

[1] Models of the early stages of basaltic eruptions beneath temperate glaciers are presented that consider the evolving sizes of volcanic edifices emplaced within subglacial cavities. The cavity size reflects the competing effects of enlargement by melting and closure by downward ductile deformation of the ice roof, which occurs when the cavity pressure is less than glaciostatic due to meltwater drainage. Eruptions of basaltic magma from fissures and point sources are considered, which form either hemicylindrical or hemispherical cavities. The rate of roof closure can therefore be estimated using Nye's law. The cavity size, edifice size, and depth of meltwater above the edifice are predicted by the model and are used to identify two potential eruption mechanisms: explosive and intrusive. When the cavity is considerably larger than the edifice, hydroclastic fragmentation is possible via explosive eruptions, with deposition of tephra by eruptionfed aqueous density currents. When the edifice completely fills the cavity, rising magma is likely to quench within waterlogged tephra in a predominantly intrusive manner. The models were run for a range of magma discharge rates, ice thicknesses and cavity pressures relevant to subglacial volcanism in Iceland. Explosive eruptions occur at high magma discharge rates, when there is insufficient time for significant roof closure. The models correctly predict the style of historic and Pleistocene subglacial fissure eruptions in Iceland and are used to explain the contrasting sedimentology of basaltic and rhyolitic tuyas. The models also point to new ways of unraveling the complex coupling between eruption mechanisms and glacier response during subglacial eruptions.

Citation: Tuffen, H. (2007), Models of ice melting and edifice growth at the onset of subglacial basaltic eruptions, J. Geophys. Res., 112, B03203, doi:10.1029/2006JB004523.

\section{Introduction}

[2] Subglacial basaltic eruptions create a variety of edifices, which include flat-topped tuyas [e.g., Mathews, 1947; Jones, 1969; Smellie and Skilling, 1994; Moore et al., 1995; Werner et al., 1996], elongate hyaloclastite ridges (tindars [e.g., Jones, 1970; Guðmundsson et al., 2002; Schopka et al., 2006]) and low-lying pillow lava sheets. The range of landforms and facies associations reflects different vent geometries, ice thicknesses and mechanisms of volcanoice interaction. Basaltic tuyas are generated by focused, large-volume eruptions (commonly $1-10 \mathrm{~km}^{3}$ ) and in Iceland are the subglacial equivalents of basaltic shield volcanoes [e.g., Rossi, 1996]. Their facies associations are well documented, from examples in Iceland, Antarctica and British Columbia [e.g., Smellie and Skilling, 1994; Moore et al., 1995; Werner et al., 1996]. Tindar ridges are considered to be the subglacial equivalents of basaltic fissure eruptions [e.g., Scemundsson, 1979; Guðmundsson et al.,

\footnotetext{
${ }^{1}$ Department of Environmental Science, Lancaster University, Lancaster,

${ }^{2}$ Formerly at Science Institute, University of Iceland, Reykjavík, Iceland.

Copyright 2007 by the American Geophysical Union. 0148-0227/07/2006JB004523\$09.00
}

2002], and although they are much more common, with possibly over a thousand examples in Iceland [Chapman et al., 2000], fewer facies studies have been carried out [Jones, 1970; Smellie and Hole, 1997; Smellie, 2001; Schopka et al., 2006]. This paper investigates the early phase of tindar and tuya-building eruptions and examines the parameters, such as magma discharge rate and cavity pressure, which may influence their mechanisms.

\subsection{Subglacial Basaltic Eruptions: Products and Processes}

[3] Typical facies associations at subglacial-to-emergent tuyas comprise a basal pillow lava pile overlain by increasingly vesicular hydroclastic tephra and capped by subaerial lava flows [e.g., Jones, 1970; Moore et al., 1995; Werner et al., 1996; Smellie, 2000]. Facies associations at tindars are essentially similar, but lack the subaerial lava cap [Smellie, 2000; Schopka et al., 2006]. The change in facies with elevation, which may be accompanied by increased degassing of the magma [Moore and Calk, 1991; Moore et al., 1995], has been thought to reflect decreasing confining pressures during construction of the subglacial edifice, which may eventually become subaerial once the ice roof has been breached. This is because both vesiculation and the explosivity of magma-water interaction are suppressed by high confining pressures [e.g., Zimanowski and Büttner, 
2003]. It has been commonly assumed that the pressure experienced by magma emplaced in a subglacial cavity is equal to the weight of the ice roof, which decreases as the edifice grows, leading to a change in eruption mechanism. Despite this, the relationship between confining pressure and eruption mechanism is not always straightforward, as pillow lavas may form beneath shallow water [Batiza and White, 2000] and explosive eruptions may occur at much higher confining pressures; for a summary, see Smellie [2000]. Factors such as the magma ascent velocity may be important in determining the explosivity of magma-water interaction as well [e.g., Jones, 1970]. Nonetheless, the stratigraphic position of pillow lavas at tuyas [e.g., Moore et al., 1995] and reconstructed paleoice thicknesses suggest that pillow lavas are typically generated beneath ice $500 \mathrm{~m}$ thick or more, corresponding to pressures $>\sim 5 \mathrm{MPa}$. This generalization is supported by observations and interpretations of the 1996 Gjálp eruption [Guðmundsson et al., 2002, 2004]. However, this issue is far from resolved, as Jones [1970], Moore and Schilling [1973], and others have suggested that, for subaqueous eruptions, only $100-200 \mathrm{~m}$ of water (1-2 MPa pressure) may be sufficient to suppress explosivity and lead to pillow formation.

[4] Dissolved water concentrations in glasses from some subglacially erupted basaltic edifices show no clear relationship with elevation. Dixon et al. [2000] attribute this to low initial water contents at a British Columbian tuya, whereas Schopka et al. [2006] suggest that water contents at an Icelandic tindar record cavity pressures that were significantly lower than glaciostatic (henceforth described as underpressured cavities). The latter theory is reinforced by the invaluable observations and models of the 1996 Gjálp eruption, which have convincingly demonstrated that underpressured cavities did develop [Guðmundsson et al., 2004]. Additionally, Höskuldsson et al. [2006] suggest that vesiculation of pillow lavas at Kverkfjöll, Iceland was triggered by a drop in subglacial cavity pressure following a jökulhlaup, supporting the idea that subglacial pressures can decrease greatly during eruptions. The existence of lowpressure subglacial cavities is well documented in the glaciological literature [e.g., Hooke, 1984; Fountain and Walder, 1998], and is due to establishment of hydrological connectivity between cavities and low-pressure areas such as the glacier snout. Factors such as the hydraulic gradient, meltwater flux and meltwater temperature influence whether this connection occurs [Hooke, 1984; Björnsson, 1988].

\subsection{Existing Models of Subglacial Basaltic Eruptions}

[5] Existing treatments of subglacial basaltic eruptions include closed-system thermodynamic models of effusive eruptions [Höskuldsson and Sparks, 1997], models of glacier fracture and dike/sill propagation [Wilson and Head, 2002] and models of magma $\rightarrow$ ice heat transfer, cavity pressure and ice deformation during the Gjálp eruption [Guðmundsson, 2003; Guðmundsson et al., 2004].

[6] In their important contribution, Höskuldsson and Sparks [1997] model the volume changes during effusion of basaltic magma at the base of a glacier. They find that the volume reduction upon melting ice is greater than the volume increase from adding the magma, which would lead to a reduction in pressure and, potentially, accumulation of meltwater. This could, however, only occur if the instantaneous magma $\rightarrow$ ice heat transfer were highly efficient ( $>80 \%$ of thermal energy transferred). Otherwise, the system volume and cavity pressure would increase, as is the case when cooler rhyolitic magma is erupted. Ice deformation is not considered in these models. Höskuldsson and Sparks use these results to argue that meltwater accumulation is possible during basaltic, but not rhyolitic eruptions.

[7] Guðmundsson [2003] and Guðmundsson et al. [2004] have since cast doubt on whether such efficient heat transfer may ever occur. Using the patterns of ice melting and meltwater drainage at Gjálp, they elegantly show that the energy transfer efficiency at the vent area during hydroclastic magma-meltwater interaction was only $55-66 \%$, and was even lower during pillow lava formation. If this is generally the case then the accumulation of meltwater during basaltic tuya-building eruptions, inferred from the sedimentology of hyaloclastites [e.g., Smellie, 2000, 2001] must be explained by another process, most plausibly through the establishment of a hydraulic potential "well" that prevents meltwater escape as the ice surface deforms above the site of melting [Björnsson, 1988]. When combined with the increasing evidence for meltwater drainage during both recent and ancient subglacial basaltic eruptions [Guðmundsson et al., 2004; Schopka et al., 2006; Smellie, 2006] this illustrates the need to develop new models of magma-ice interaction that account for underpressured cavities, ice deformation and meltwater drainage.

[8] Wilson and Head [2002] consider the mechanisms of dike-fed subglacial basaltic eruptions, and suggested that dikes or sills may propagate into the glacier base, depending upon the pressures driven by volatile degassing. They infer that the ice may be fractured by the rifting associated with dike intrusion, leading to rapid melting over a large surface area. Although this original approach encapsulates many aspects of dike-fed eruptions, especially beneath frozenbased glaciers where the ice is strongly coupled to the bedrock, there is currently no geological evidence to support it, and the early stage of subglacial eruptions is thought to occur in a cavity melted by magmatic heat [e.g., Guðmundsson, 2003].

[9] In the light of the geological and observational evidence, what is therefore required is a model that accounts for underpressured, drained cavities with deforming ice roofs and in which changes in cavity conditions (e.g., pressure) trigger transitions between different styles of eruption. Similar models have been developed for subglacial rhyolite eruptions [Tuffen, 2001; Tuffen et al., 2007b], which examine the evolving sizes of underpressured subglacial cavities and the volcanic edifices growing within them. They show that closure of the ice roof onto the edifice is more important at high underpressures and at low magma discharge rates and can potentially lead to an intrusive style of eruption if the edifice completely fills the cavity and rising magma is then quenched within the edifice. These models assumed eruptions occurred from point sources and built hemispherical edifices, with $100 \%$ efficient magma $\rightarrow$ ice energy transfer and cavities at atmospheric pressure. It was also assumed that the eruption mechanism (e.g., pillow formation/hydroclastic eruption) was insensitive to the confining pressure. These models have been refined here to account for basaltic eruptions 


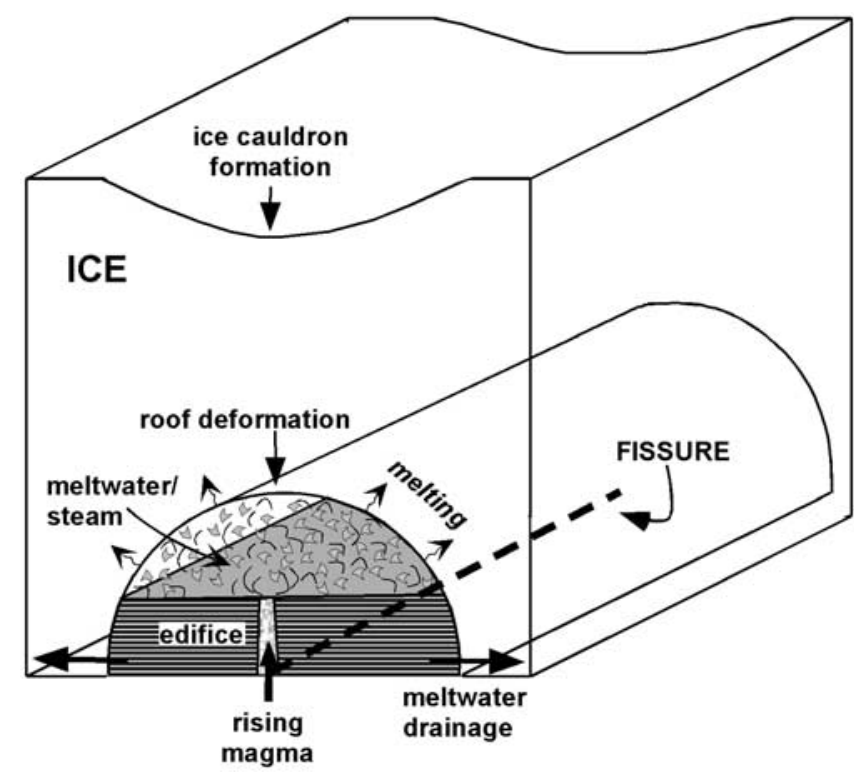

Figure 1. Cartoon showing a fissure eruption at the base of a glacier. A hemicylindrical cavity has been melted above the fissure and a flat-topped volcanic edifice is emplaced within it. Any space above the edifice is filled by meltwater, possibly with some steam, which provides space for explosive magma-water interaction. Meanwhile, the cavity roof closes toward the edifice, forming an ice cauldron on the glacier surface. Meltwater drains away from the eruption site at the glacier base.

from elongate fissures, with underpressures and efficiencies similar to those inferred for Gjálp and eruption mechanisms that also depend upon the cavity pressure.

\subsection{Evidence From the 1996 Gjálp Eruption and Models of Guðmundsson}

[10] Observations and models of the 1996 Gjálp eruption, as described by Guðmundsson [2003] and Guð̆mundsson et al. [1997, 2002, 2004] have provided unprecedented insights into the mechanisms of volcano-ice interaction, some of which are listed below. (1) Deformation of the 450-650 $\mathrm{m}$ thick ice above the eruption site was initially ductile. (2) The initial high heat flux and the density of the edifice both indicate that primarily hyaloclastite was erupted. (3) Although meltwater drained from the eruption site, a column of meltwater accumulated above the edifice. (4) The well-drained subglacial cavity above the southern part of the fissure had an underpressure of about $2 \mathrm{MPa}$. (5) The glacier at the northern part of fissure was lifted by overpressured meltwater and pillow lavas were formed at a confining pressure of $>5 \mathrm{MPa}$, leading to delayed melting. (6) The heat transfer efficiency between magma and ice at the eruption site, $f_{i}$, was between 0.55 and 0.66 . This rises to 0.62 to 0.77 if ice melted on the drainage path is also considered. (7) Less than $10 \%$ of the erupted products were washed away by meltwater. (8) The $\sim 0.7 \mathrm{~km}^{3}$ edifice was erupted at up to $\sim 1000 \mathrm{~m}^{3} \mathrm{~s}^{-1}$ from a $6 \mathrm{~km}$ fissure. (9) The heat flux during the eruption was 10-20 times that during slow cooling.
[11] What is not known about the Gjálp eruption is how the magma discharge rate varied with time, what morphology the enlarging subglacial cavity had and what sedimentological features formed in the hyaloclastite. It is also unclear how typical the eruption was, although the widespread basaltic hyaloclastite ridges in Iceland such as Helgafell [Schopka et al., 2006] were probably formed in very similar eruptions. Despite these minor reservations, many of the parameters that are well constrained for Gjálp will be used in the model presented here.

\subsection{Ice Deformation During Subglacial Eruptions}

[12] The roof of an underpressured subglacial cavity will close inward due to the weight of the glacier above. If the cavity radius is small compared to the ice thickness, then deformation will be ductile, and the rate of closure of cylindrical or spherical cavities can be approximated by Nye's law [Nye, 1953], depending upon cavity size and underpressure. Closure of the cavity roof will lead to depression of the ice surface above and formation of an ice cauldron [e.g., Guðmundsson et al., 1997]. As the cavity size increases, strain rates in the ice above exceed the threshold for ductile deformation, and brittle failure of the ice occurs. This is illustrated by observations of developing ice cauldrons during subglacial eruptions and geothermal melting events in Iceland [e.g., Björnsson, 1988; Guðmundsson et al., 1997; Jönsson et al., 1998; Guðmundsson, 2005]. Typically, the glacier surface remains smooth during the initial phase of cauldron development, and becomes fractured at a later stage, often once the cauldron exceeds $50 \mathrm{~m}$ in depth. Since the deformation behavior of ice is pressure-dependent [e.g., Mizuno, 1998], ductile deformation may continue at depth, even when the ice surface is deforming brittly, but the depth of brittle failure is likely to increase with time. With continued melting, the center of the cauldron then undergoes piston-like subsidence, bounded by arcuate fractures, until the cavity roof eventually fails and a subaerial eruption may eventually ensue [Guðmundsson et al., 1997, 2004].

\section{Outline of the Analytical Model}

[13] This paper considers eruptions from elongate fissures and point sources at the base of horizontal, wet-based ice sheets at $0^{\circ} \mathrm{C}$. The magma discharge rate per unit length of fissure is assumed to be constant and a range of magma discharge rates, ice thicknesses and cavity pressures are considered. Heat from the magma melts a hemicylindrical (Figure 1) or hemispherical cavity in the glacier base. The cavity roof closes by ductile ice flow at a rate approximated by Nye's law and simulations are stopped once the cavity reaches $25 \%$ of the initial ice thickness, whereupon Nye's law is likely to break down as brittle ice deformation becomes important. The evolving cavity size reflects the competing effects of melting and closure. A volcanic edifice is constructed within the cavity (Figure 1), consisting of pillow lavas when cavity pressures exceed $5 \mathrm{MPa}$ and hydroclastic tephra when pressures are less than $5 \mathrm{MPa}$ (Figure 2). Although meltwater can escape from the cavity, an assumption of the model is that any gap above the edifice will be filled with meltwater (Figure 1). It is possible that some steam will also be present [Tuffen et al., 2002a], 


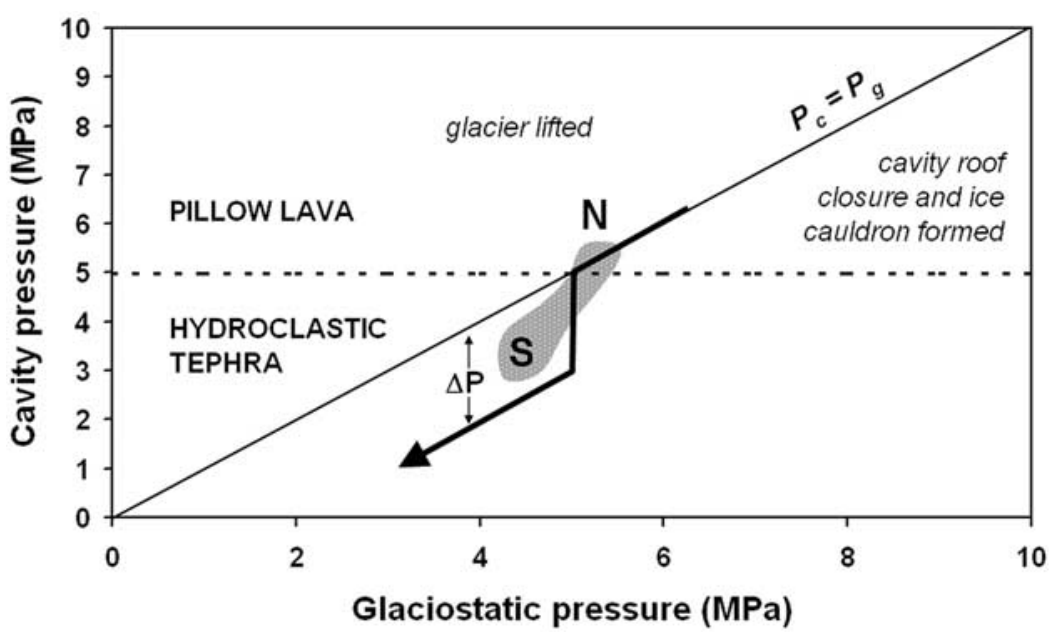

Figure 2. Diagram indicating the possible relationship between cavity pressure $\left(P_{c}\right)$ and glaciostatic pressure $\left(P_{g}\right)$ during subglacial eruptions. To the left of the diagonal line $P_{c}=P_{g}$, the glacier is lifted; to the right, cavity underpressure (indicated by $\Delta P$ ) leads to cavity roof closure and ice surface deformation. The shaded area indicates the probable pressure conditions during the Gjálp eruption [from Guðmundsson et al., 2004], with the northern (N) and southern (S) ends of the fissure indicated. The arrow indicates the inferred pressure path during an eruption that starts with pillow effusion but becomes explosive as roof thinning reduces the cavity pressure to less than $5 \mathrm{MPa}$.

depending on the relative rates of magma-meltwater and meltwater-ice heat transfer, but the amount of steam will not be quantified here. The model predicts how the edifice grows and the cavity enlarges during the early stages of an eruption and also indicates the depth of meltwater/steam above the edifice. Table 1 lists the variables and constants used.

[14] The effects of different cavity underpressures on the cavity evolution are studied, and additionally some runs are carried out with underpressures of $2 \mathrm{MPa}$, which is the value inferred for the southern end of the Gjálp fissure. In the latter case it is assumed that the cavity remains at glaciostatic pressure until this is less than $5 \mathrm{MPa}$, at which case an underpressure of $2 \mathrm{MPa}$ develops (Figure 2). This is consistent with the transition from undrained pillow lava effusion (as occurred at the north end of the Gjálp fissure) to a well-drained hydroclastic eruption. A general model that predicts the underpressure solely based on the thermodynamics of an eruption [e.g., Höskuldsson and Sparks, 1997] is not globally applicable as it cannot deal with the hydrological patterns that are unique to each eruption site. The model is applied to eruptions from both point sources and elongate fissures.

\subsection{Heat Transfer From Magma to Ice}

[15] The total amount of thermal energy released by cooling and crystallizing basaltic magma, $\mathrm{E}_{\mathrm{T}}$, is given by

$$
E_{T}=\rho_{l}\left(c_{l} \Delta T_{l}+\Delta x L_{l}\right)
$$

where $\rho_{l}$ denotes magma density, $c_{l}$ denotes magma heat capacity, $\Delta T_{l}$ denotes the temperature change of the magma, $\Delta x$ denotes the change in crystallinity and $L_{L}$ denotes the heat of fusion of the magma [Höskuldsson and Sparks, 1997]. This energy is dominated by the contribution from the change in magma temperature, with even complete crystallization of the magma contributing less than $15 \%$ of $E_{T}$. Given that the analysis in this paper is only approximate, initial phenocryst contents can vary widely and subglacially erupted basaltic deposits can vary from glassy (common in hyaloclastites [e.g., Jones, 1970]) to mostly crystalline (common in intrusions and pillows [e.g., Schopka et al., 2006]), the effects of crystallization will be ignored and so equation (1) condenses to

$$
E_{T}=\rho_{l} c_{l} \Delta T_{l}
$$

and $E_{T}$ is thus the maximum thermal energy that can be transferred from the unit volume of magma to the ice. In order to simplify matters, all magma is assumed to be vesicle-free, although the presence of vesicles reduces the value of $\mathrm{E}_{\mathrm{T}}$ [see Höskuldsson and Sparks, 1997].

\subsection{Mechanisms and Efficiency of Heat Transfer}

[16] Whereas much of the heat in rising magma is rapidly released during contact with meltwater, the remainder is more slowly released from material buried within the edifice [Guðmundsson, 2003]. The models presented here consider only rapid energy release; the energy released during slow cooling is ignored. The heat transfer efficiency $f_{i}$ is the fraction of the magmatic heat energy that is transferred nearinstantaneously to melt ice [Guðmundsson, 2003; Guðmundsson et al., 2004]. This is somewhat less than the efficiency of heat transfer from magma, as $f_{i}$ accounts for the $10-20 \%$ of magmatic heat energy that may be used to heat meltwater by $10-20^{\circ} \mathrm{C}$ and then lost from the system [Guðmundsson, 2003]. Therefore the heat flux available for ice melting $Q_{m}$ is equal to

$$
Q_{m}=Q_{l(t)} E f_{i}
$$


Table 1. Variables and Constants Used in the Models ${ }^{\mathrm{a}}$

\begin{tabular}{|c|c|c|}
\hline Symbol & Definition & Units \\
\hline$Q$ & heat output & W \\
\hline$E$ & energy/magma volume & $\mathrm{J} \mathrm{m}^{-3}$ \\
\hline $\mathrm{V}$ & volume & $\mathrm{m}^{3}$ \\
\hline$R$ & radius & $\mathrm{m}$ \\
\hline$Q_{l}$ & magma discharge rate & $\mathrm{m}^{3} \mathrm{~s}^{-1}$ \\
\hline$r^{\prime}$ & rate of change of radius & $\mathrm{m} \mathrm{s}^{-1}$ \\
\hline$v$ & ice melted/magma volume & - \\
\hline $\mathrm{T}$ & temperature & ${ }^{\circ} \mathrm{C}$ \\
\hline$\Delta \mathrm{T}$ & temperature change & ${ }^{\circ} \mathrm{C}$ \\
\hline$P$ & pressure & $\mathrm{Pa}$ \\
\hline$\Delta P$ & pressure difference & $\mathrm{Pa}$ \\
\hline$\rho$ & density & $\mathrm{kg} \mathrm{m}^{-3}$ \\
\hline$c$ & specific heat capacity & $\mathrm{J} \mathrm{kg}^{-1}{ }^{\circ} \mathrm{C}^{-1}$ \\
\hline$\theta$ & magma vesicularity & - \\
\hline$t$ & time & $\mathrm{s}$ \\
\hline$L$ & heat of fusion & $\mathrm{J} \mathrm{kg}^{-1}$ \\
\hline $\mathrm{x}$ & magma crystallinity & - \\
\hline $\mathrm{g}$ & gravitational constant & $9.81 \mathrm{~m} \mathrm{~s}^{-2}$ \\
\hline $\mathrm{n}$ & Glen's flow law constant & 3 \\
\hline B & ice viscosity parameter & $5.3 \times 10^{7} \mathrm{~Pa} \mathrm{~s}^{1 / 3}$ \\
\hline$S$ & packing coefficient & - \\
\hline \multicolumn{3}{|c|}{ Properties of Ice } \\
\hline $\mathrm{T}_{\mathrm{i}}$ & & $0^{\circ} \mathrm{C}$ \\
\hline$\rho_{i}$ & & $917 \mathrm{~kg} \mathrm{~m}^{-3}$ \\
\hline$L_{i}$ & & $3.35 \times 10^{5} \mathrm{~J} \mathrm{~kg}^{-1}$ \\
\hline \multicolumn{3}{|c|}{ Properties of Rhyolitic Magma } \\
\hline$T_{l}$ & & $900^{\circ} \mathrm{C}$ \\
\hline$\rho_{l}$ & & $2300 \mathrm{~kg} \mathrm{~m}^{-3}$ \\
\hline$c_{l}$ & & $1.04 \mathrm{~kJ} \mathrm{~kg}^{-1}{ }^{\circ} \mathrm{C}^{-1}$ \\
\hline \multicolumn{3}{|c|}{ Properties of Basaltic Magma } \\
\hline$T_{l}$ & & $1200^{\circ} \mathrm{C}$ \\
\hline$\rho_{l}$ & & $2700 \mathrm{~kg} \mathrm{~m}^{-3}$ \\
\hline$c_{l}$ & & $1.20 \mathrm{~kJ} \mathrm{~kg}^{-1}{ }^{\circ} \mathrm{C}^{-1}$ \\
\hline
\end{tabular}

where $\mathrm{Q}_{1(\mathrm{t})}$ is the instantaneous magma discharge rate and $\mathrm{E}$ is the total thermal energy per unit volume of the magma. Three different heat transfer efficiencies for three distinct eruption scenarios are considered.

2.2.1. Pillow Lava Formation $(\mathrm{P}>5 \mathrm{MPa})$

[17] Conductive heat loss from pillow lavas is retarded by the formation of a chilled rind, and accelerated by fracturing of the pillows [e.g., Höskuldsson and Sparks, 1997; Tuffen et al., 2002a; Wilson and Head, 2002]. Cooling models indicate that individual pillows may take $\sim 10^{5} \mathrm{~s}$ to cool [Höskuldsson and Sparks, 1997] and the effective heat transfer efficiency from the edifice may be as low as 0.1 , if the heat flux from buried pillows is ignored [Guðmundsson, 2003]. A value of $f_{i}=0.1$ is used for the models in this scenario.

\subsubsection{Hydroclastic Eruptions $(\mathrm{P}<5 \mathrm{MPa}$, Cavity Not Completely Filled by Edifice)}

[18] Heat loss from magma during hydroclastic eruptions is much more rapid, due to the significantly higher surface area for heat exchange [e.g., Dobran and Papale, 1993; Zimanowski et al., 1997]. This is demonstrated by the far greater surface area/volume ratio of typical hydroclastic tephra $\left(3000 \mathrm{~m}^{-1}\right)$ than typical pillow lavas $\left(12 \mathrm{~m}^{-1}\right)$. These values were calculated for spherical bodies with the sizes of hydroclasts $(0.25 \mathrm{~mm}$ radius $)$ and pillows $(0.25 \mathrm{~m}$ radius) taken from Smellie and Hole [1997].

[19] Estimates of the diffusion time for heat loss from magma fragments and observations of the 1996 Gjálp eruption suggest that $f_{i}$ may be in the range $0.5-0.61$ [Guðmundsson, 2003, Guðmundsson et al., 2004]. The efficiency of heat transfer from magma $(0.63-0.77)$ was somewhat greater. In order to fully cover the plausible range of $f_{i}$, values of 0.5 and 0.7 are used for this scenario in the models. The latter value is relevant to more thermally efficient melting than Gjálp, where little heat energy is lost as the meltwater is heated by less than $10^{\circ} \mathrm{C}$. The effects of confining pressure upon phreatomagmatic fragmentation processes, and the consequences for heat transfer efficiencies, are not well understood, so $f_{i}$ is assumed not to change with cavity pressure. Also, it is important to note that the factors controlling meltwater temperature during a given eruption are not currently known.

\subsubsection{Intrusive Eruption (When Cavity Filled)}

[20] If the edifice completely fills the cavity, rising magma intrudes and quenches within the slowly cooling edifice and only a small proportion of rising magma reaches the glacier base [Tuffen et al., 2001, 2002a]. The rate of heat transfer will therefore be similar to that from a cooling volcanic edifice shortly after the end of an explosive eruption. As the flux of residual heat from the newly formed Gjálp edifice was $\sim 5-10 \%$ that of the heat flux during the eruption [Guðmundsson et al., 2004], a value of 0.1 will be taken for $f_{i}$.

\subsection{Melting of Ice}

[21] Heat energy from the magma is used to melt ice and to heat and potentially vaporize the meltwater formed. The meltwater temperature may be in the range $0-20^{\circ} \mathrm{C}$ or even higher [e.g., Guðmundsson et al., 1997, 2004] and in some cases a small quantity of steam may be even be generated, especially at low confining pressures, although the thermal effect of steam formation will not be addressed here. The volume of ice melted per unit volume of magma $v_{i}$ is given by

$$
\left.v_{i}=\frac{f_{i}}{\rho_{i} L_{i}}\left[c_{l} \rho_{l} \Delta T_{l}\right)\right]
$$

where $f_{i}$ is the magma $\rightarrow$ ice heat transfer efficiency (as described by Guðmundsson [2003] and Guðmundsson et al. [2004]), $\rho_{i}$ is the density of ice, and $L_{i}$ is the heat of fusion of ice.

[22] Melting is assumed to occur evenly over the roof of a hemicylindrical or hemispherical cavity of radius $R$ (Figure 1). The melt-back rate $r_{m}^{\prime}$ is given by

$$
r_{m}^{\prime}=\frac{v_{i} Q_{l}}{2 \pi R^{2}}
$$

for a hemispherical cavity and

$$
r_{m}^{\prime}=\frac{v_{i} Q_{l}}{\pi R L}
$$


for a hemicylindrical cavity, where $Q_{l}$ is the magma discharge rate in $\mathrm{m}^{3} \mathrm{~s}^{-1}$ and $L$ is the fissure length.

\subsection{Deformation of Ice}

[23] According to Nye's law, the roof of a cylindrical or spherical cavity within an infinite ice sheet will deform at a rate $R_{d}^{\prime}$ given by

$$
R_{d}^{\prime}=R\left[\frac{\Delta P}{n B}\right]^{n}
$$

and

$$
R_{d}^{\prime}=3 R\left[\frac{\Delta P}{2 n B}\right]^{n}
$$

respectively, where $\Delta P$ is the cavity underpressure, $n$ is Glen's flow law constant $(\approx 3)$ and $B$ is an ice deformation parameter, taken as $5.3 \times 10^{7} \mathrm{~Pa} \mathrm{~s}^{1 / 3}$ [e.g., Hooke, 1984]. These deformation rates are applied to hemicylindrical and hemispherical cavities, although basal drag may inhibit wall closure and lead to a broader cavity shape [Hooke et al., 1990]. Nye's law applies when the cavity radius is small compared to the ice thickness [Nye, 1953], but breaks down at large cavity sizes because variations in the confining stress at the cavity roof become significant, heterogeneous strain within the ice leads to spatial variations in rheology and ice may deform brittly. For the purpose of this paper, it is assumed that Nye's law will provide an adequate approximation of deformation rates when the cavity radius is less than $25 \%$ of the ice thickness (i.e., the early stages of an eruption). This corresponds to the approximate cavity size at which brittle deformation of the ice surface above becomes important (M. T. Guðmundsson, personal communication, 2002). It is important to recognize that Nye's law only applies to hemispherical or hemicylindrical cavities. Closure of irregularly shaped cavities can only be simulated by two or three dimensional models [e.g., Cutler, 1998], which are beyond the scope of this paper.

\subsection{Cavity Pressure}

[24] Two cavity pressure regimes are considered in the models. First, runs have been carried out using a range of different cavity underpressures between 1 and $5 \mathrm{MPa}$, to investigate how different underpressures beneath a given ice thickness affect the evolution of the cavity and the eruption mechanism. Secondly, a more realistic scenario is considered, which is based on the inferred pressure conditions during the Gjálp eruption and illustrated in Figure 2. Here cavity pressure is assumed to be glaciostatic when the glaciostatic pressure exceeds $5 \mathrm{MPa}$, with formation of pillow lavas. However, once the glaciostatic pressure falls to less than $5 \mathrm{MPa}$, due to roof thinning, an underpressure of $2 \mathrm{MPa}$ develops and a hydroclastic eruption occurs. The underpressure in the cavity $\Delta P$, which drives closure of the cavity roof, is defined as

$$
\Delta P=P_{g}-P_{c}
$$

where $P_{g}$ is the pressure from the overlying ice and $P_{c}$ is the cavity pressure. The maximum possible underpressure
$\Delta P_{\max }$ occurs when the cavity is at atmospheric pressure $(\sim 0.1 \mathrm{MPa})$, and is given by

$$
\Delta P_{\max }=\rho_{i} g h_{i}-0.1 \mathrm{MPa}
$$

where $\rho_{i}$ is ice density, $\mathrm{g}$ is gravitational acceleration and $h_{i}$ is the roof thickness. During melting, $h_{i}$ will decrease, and lead to a reduction in $\Delta P_{\max }$.

\subsection{Cavity Size Evolution}

[25] The rate at which the cavity size changes is determined by the relative rates of enlargement by melting and closure by deformation. The rate of cavity enlargement $d R / d t$ is thus given by the following relation:

$$
\frac{d R}{d t}=r_{m}^{\prime}-r_{d}^{\prime}
$$

Substituting equation (5) or (6) for $r_{m}^{\prime}$ and equation (7) or (8) for $r_{d}^{\prime}$ into (11) yields

$$
\frac{d R}{d t}=\frac{v_{i} Q_{l}}{\pi R L}-R\left[\frac{\Delta P}{n B}\right]^{n}
$$

for a hemicylindrical cavity and

$$
\frac{d R}{d t}=\frac{v_{i} Q_{l}}{2 \pi R^{2}}-3 R\left[\frac{\Delta P}{2 n B}\right]^{n}
$$

for a hemispherical cavity, where $Q_{l}$ is the volume flux of magma $\left(\mathrm{m}^{3} \mathrm{~s}^{-1}\right)$. Equations (12) and (13) can be combined with equation (4), for $v_{i}$, to give

$$
\frac{d R}{d t}=\frac{Q_{l}}{\pi R L}\left[\frac{f_{i}}{\rho_{i} L_{i}}\left[c_{l} \rho_{l} \Delta T_{l}\right]\right]-R\left[\frac{\Delta P}{n B}\right]^{n}
$$

and

$$
\frac{d R}{d t}=\frac{Q_{l}}{2 \pi R^{2}}\left[\frac{f_{i}}{\rho_{i} L_{i}}\left[c_{l} \rho_{l} \Delta T_{l}\right]\right]-3 R\left[\frac{\Delta P}{2 n B}\right]^{n}
$$

for hemicylindrical and hemispherical cavities, respectively.

[26] Equations (14) and (15) have been solved numerically, providing values of melt-back rate, ice deformation rate and cavity radius that were calculated incrementally over a series of time steps where $t_{n+1}=1.01 t_{n}$. Simulations were continued until the cavity radius reached $25 \%$ of the initial ice thickness.

[27] Initially, melting is focused over a small surface area and the cavity radius increases rapidly, at $10^{-2}-10^{-3} \mathrm{~m} \mathrm{~s}^{-1}$. These rates are similar to melting rates estimated by Höskuldsson et al. [2006] and inferred from observations of the 1996 Gjálp eruption [Guðmundsson et al., 1997]. However, the melt-back rate soon drops and the rate of closure increases as the cavity grows. If the melting rate and underpressure are constant, the cavity radius may reach an equilibrium value, at which melting balances deformation [Tuffen et al., 2002a]. However, this is unlikely to occur unless the melting rate is very low; the cavity size never 
reaches equilibrium for any of the eruptions considered in this paper.

\subsection{Edifice Volume and Space in Cavity}

[28] Assuming that the amount of erupted material removed by flowing meltwater is negligible, the edifice volume $\mathrm{V}_{e}$ is given by

$$
V_{e(t)}=\int_{0}^{t} Q_{l} S d t
$$

where $S$ is a packing coefficient, equal to 1 for pillow lava and 1.9 for hyaloclastite (based on a dry density of $1400 \mathrm{~kg} \mathrm{~m}^{-3}$ for the hyaloclastite ridge formed in the Gjálp eruption, and a magma density of $2600 \mathrm{~kg} \mathrm{~m}^{-3}$ [Guðmundsson et al., 2002]). The value for hyaloclastite is greater than 1 due to pore space between particles. It is assumed that the top of the edifice is horizontal when a water column is present, as in subglacial basaltic successions the generally gentle dip of bedding planes in hydroclastic tephra (excluding foreset bedding) reflects deposition from subaqueous density currents [e.g., Jones, 1970; Smellie and Hole, 1997; Werner and Schmincke, 1999]. In this case, the height of the edifice $\mathrm{h}_{\mathrm{e}}$ can be calculated from the relations

$$
\sin ^{-1}(X)+X \sqrt{\left(1-X^{2}\right)}-\frac{\pi Y}{2}=0
$$

for a hemicylindrical cavity and

$$
X^{3}-3 X+2 Y=0
$$

for a hemispherical cavity, where $\mathrm{X}=\mathrm{h}_{\mathrm{e}} / \mathrm{R}$ and $\mathrm{Y}=$ edifice volume/cavity volume.

[29] Tuffen [2001] and Tuffen et al. [2007b] envisage two scenarios: one in which the cavity enlarges more quickly than the edifice and meltwater/steam is always present (A), and one in which the edifice completely fills the cavity (B). 2.7.1. Edifice Radius Less Than Cavity Radius

[30] For this scenario a significant column of meltwater and/or steam exists above the growing edifice, and rising magma can interact explosively with meltwater if the cavity pressure is sufficiently low (for the purposes of this model, $<5 \mathrm{MPa}$ ). A Surtseyan style of eruption will occur, with tephra jets feeding subaqueous debris currents [e.g., White, 1996, 2000; Smellie, 2001]. Fragmentation permits rapid heat transfer from magma to meltwater [Dobran and Papale, 1993; Zimanowski et al., 1997; Guðmundsson, 2003], and the heat transfer efficiency from magma to ice may be as high as 0.66 [Guðmundsson et al., 2004]. Rising magma cools in contact with meltwater/steam rather than within the edifice and edifice growth is predominantly exogenous. This inference is supported by field evidence from Surtseyan subglacial basaltic successions in Antarctica [Smellie and Hole, 1997; Smellie, 2001], where the paucity of fragments of the underlying pillow lava pile indicates that explosive fragmentation occurred at or very close to the edifice-meltwater interface.

[31] The grain size of the phreatomagmatic tephra formed will depend upon the explosivity of magma-water interaction and be influenced by the confining pressure and the ability of magma and water to mix [e.g., Wohletz, 1983; Zimanowski et al., 1997]. The structure of the deposits may be variable, as they will reflect a wide variety of potential emplacement mechanisms, such as high- and low-concentration turbidity currents, grain flows and debris flows [White, 1996; Smellie and Hole, 1997; White, 2000; Smellie, 2001], and the eruption may be continuous or pulsatory. Nonetheless, there is the potential for wellstratified deposits to be generated, as there is scope for significant horizontal and vertical translation of particles in water-supported currents. The sedimentology of the tephra formed is further discussed in section 3.4.

\subsubsection{Edifice Fills Cavity}

[32] If the edifice completely fills the cavity, there is no column of meltwater/steam within which explosive hydroclastic fragmentation can occur and no scope for transport of particles by water-supported currents. The eruption mechanism is therefore likely to be dominantly intrusive, with rising magma being quenched within the edifice. The geological record of this activity may be pillow lavas that intrude wet, poorly consolidated hyaloclastite, similar to facies CH-P of Werner and Schmincke's [1999] study. Wellstratified deposits will not be generated, even if the eruption were pulsatory. In rhyolitic eruptions, intrusive lava lobes within quench hyaloclastite are formed and a small proportion of the magma may still reach the glacier base, where it triggers localized melting [Tuffen et al., 2002a]. The melting rate is likely to be much lower than during hydroclastic fragmentation, and $f_{i}$ is estimated to be only 0.1 . The eruption mechanism will remain intrusive unless sufficient magma rises to the glacier base to melt a new cavity above the edifice.

\section{Results of the Models}

[33] The model calculates the radius of the growing edifice and evolving subglacial cavity, and also the elevation of the ice surface. Figure 3 shows typical graphs produced by the model, for initially hydroclastic eruptions beneath ice $600 \mathrm{~m}$ thick. Deformation is insignificant when the magma discharge rate is high (Figure 3a), and a considerable water column develops above the edifice, providing scope for tephra deposition by eruption-fed aqueous density currents. Ice deformation is much more important at lower magma discharge rates (Figure 3b), and the edifice: cavity volume ratio increases to 1 , in which case the edifice completely fills the cavity, leading to an intrusive style of eruption.

\subsection{Explosive or Intrusive Eruptions?}

[34] The critical magma discharge rate $\mathrm{Q}_{\mathrm{cr}}$ was determined for a specified vent geometry, cavity underpressure, magma type and heat transfer efficiency. Below $\mathrm{Q}_{\mathrm{cr}}$, the edifice fills the cavity, favoring an intrusive eruption. Above $\mathrm{Q}_{\mathrm{cr}}$, the edifice never completely fills the cavity, and the eruption is assumed to be explosive throughout. The model was run for a range of ice thicknesses (Figure 4). It must be noted that these calculations have been carried out for confining pressures $<5 \mathrm{MPa}$. For comparison, equivalent values for rhyolitic magma are also given. As may be expected, intrusive eruptions are favored by high cavity underpressure and low magma discharge rate. $Q_{\mathrm{cr}}$ is con- 

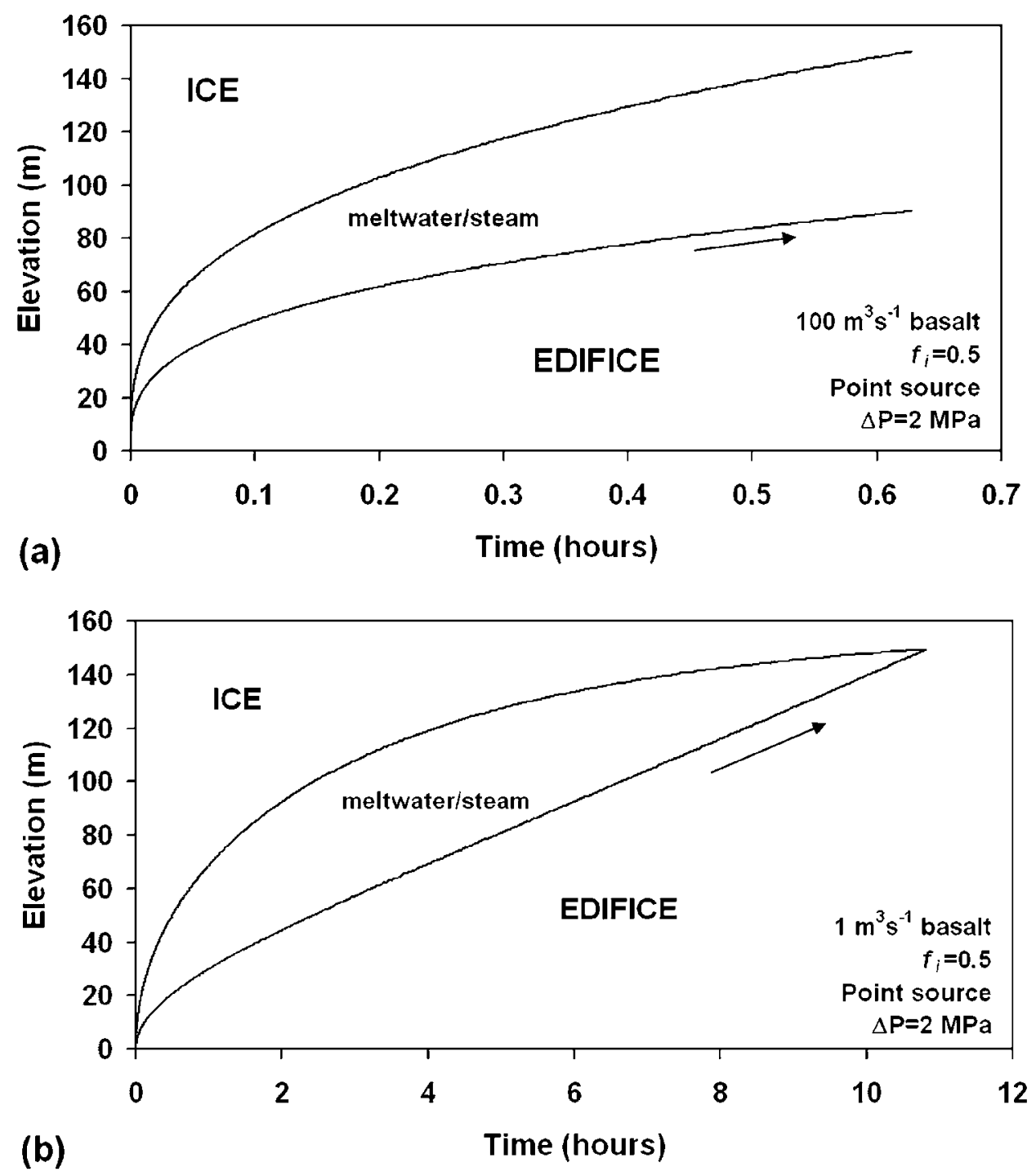

Figure 3. Graphs showing the position of the cavity roof and top of the edifice during two eruptions from a point source beneath $600 \mathrm{~m}$ of ice. (a) At a high magma discharge rate $\left(100 \mathrm{~m}^{3} \mathrm{~s}^{-1}\right)$, the cavity size increases much more quickly than the edifice, creating a significant depth of meltwater/steam in which hydroclastic fragmentation can occur. (b) At a lower magma discharge rate, closure of the cavity is more important and the edifice soon completely fills the cavity (arrow), leading to an intrusive style of eruption.

siderably lower for eruptions from point sources because melting is more focused. $Q_{\mathrm{cr}}$ is a factor of $\sim 2$ lower for basalt than rhyolite, due to its higher initial magma temperature. Similarly, $\mathrm{Q}_{\mathrm{cr}}$ is lowest for a given magma type and magma discharge rate if the heat transfer efficiency is high during an eruption. A similar technique has been used to estimate the magma discharge rate during Quaternary subglacial rhyolite eruptions at Torfajökull, Iceland [Tuffen et al., 2007b].

[35] The potential mechanisms of subglacial basaltic fissure eruptions have been explored by using known magma discharge rates from historical subaerial eruptions in Iceland as inputs for the model, together with the inferred ice thicknesses, cavity pressures and approximate magma discharge rates during 20th century subglacial eruptions.

\subsection{Simulations of 20th Century Icelandic Eruptions}

[36] The two largest subglacial basaltic eruptions in Iceland in the 20th century were those at Katla in 1918 and Gjálp in 1996 [Guðmundsson, 2005]. The Katla 1918 eruption occurred on a $\sim 2 \mathrm{~km}$ fissure beneath $450 \mathrm{~m}$ of ice and formed glassy tephra generated by explosive magma-water interaction, much of which was removed from the eruption site and deposited on the sandur by a $1-8 \mathrm{~km}^{3}$ jökulhlaup. The magma discharge rate could have been as high as $10^{4} \mathrm{~m}^{3} \mathrm{~s}^{-1}$ during the $\sim 2$ hour subglacial phase [Guðmundsson and Cook, 2004], and the underpressure is not known. As summarized in section 1.4, the Gjálp eruption occurred on a $6 \mathrm{~km}$ long fissure beneath 450 $650 \mathrm{~m}$ of ice and involved both hydroclastic fragmentation and pillow lava effusion. The magma discharge rate is estimated at $\sim 1000 \mathrm{~m}^{3} \mathrm{~s}^{-1}$ for the first two days (calculated 


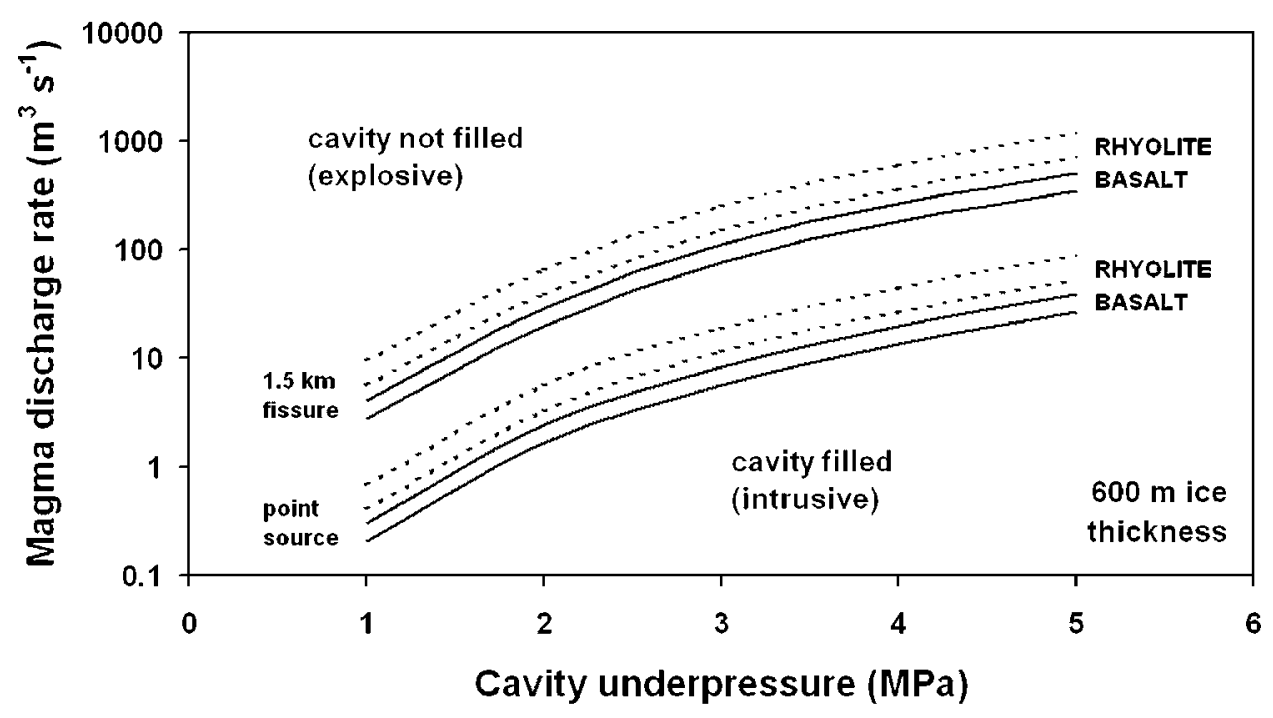

Figure 4. Critical magma discharge rate $Q_{c r}$ shown as a function of cavity underpressure, for eruptions beneath $600 \mathrm{~m}$ of ice. Dotted lines indicate rhyolite; solid lines indicate basalt. $Q_{c r}$ for eruptions from point sources and $1.5 \mathrm{~km}$ fissures are given. In each case, two curves are given: top one is for $f_{i}=0.5$, and bottom one is for $f_{i}=0.7$.

by Guðmundsson et al. [2004]), and the underpressure was between 0 and $2 \mathrm{MPa}$.

[37] This data has been plotted on Figure 5, together with the critical magma discharge rates for basaltic eruptions on a $1.5 \mathrm{~km}$ fissure beneath $600 \mathrm{~m}$ of ice. For the Katla and Gjálp eruptions, the magma discharge rate per $1.5 \mathrm{~km}$ of fissure has been used, which enables direct comparison with the modeled values of $\mathrm{Q}_{\mathrm{cr}}$. It is seen that both eruptions plot firmly in the "explosive" field for all plausible values of cavity underpressure, which is consistent with the explosive hydroclastic fragmentation that dominated both eruptions. This means that the emplacement of pillows at the northern end of the Gjálp fissure was probably due to high confining pressure, as suggested by Guðmundsson et al. [1997], rather than cavity filling and the transition to an intrusive eruption.

[38] It is also instructive to consider what would have happened if historic basaltic eruptions in Iceland had occurred beneath ice. The eruptions chosen are Laki 1783, Heimæy 1973 and Krafla 1975-1984, as the magma discharge rate and fissure length for all three are well constrained [Thordarson and Self, 1993; Thorarinsson et al., 1973; Harris et al., 2000]. In each case the peak discharge rate was taken and normalized to the rate per $1.5 \mathrm{~km}$ of fissure. All eruptions except Krafla 1984 plot well within the explosive field for a reasonable underpressure of $2 \mathrm{MPa}$ (Figure 5), indicating that the explosive magmawater interactions should be common for subglacial fissure eruptions. It is further inferred that suppression of explosivity during fissure eruptions may be primarily controlled by high confining pressures rather than low magma discharge rates. Even if tuya-building eruptions involved the low magma discharge rates of $5-10 \mathrm{~m}^{3} \mathrm{~s}^{-1}$ inferred for postglacial shield volcanoes [Rossi, 1996], the eruptions will still fall within the explosive field, as they occur from point sources, which require much lower values of $\mathrm{Q}_{\mathrm{cr}}$ than elongate fissures (Figure 4).
[39] Flow localization is an important phenomenon during basaltic fissure eruptions [e.g., Wylie et al., 1999] and in subglacial eruptions could lead to a change from fissure to a point source, with melting becoming focused over a hemispherical cavity roof. Given that $\mathrm{Q}_{\mathrm{cr}}$ is significantly lower for point sources than fissure eruptions (Figure 4), this may cause initially intrusive eruptions to become explosive. An example of fissure focusing occurred during the 1973 Eldfell eruption at Heimæy, Iceland, when a magma discharge rate of $100 \mathrm{~m}^{3} \mathrm{~s}^{-1}$ on a $1.5 \mathrm{~km}$ long fissure dwindled to $10 \mathrm{~m}^{3} \mathrm{~s}^{-1}$ from a point source [Thorarinsson et al., 1973]. The changing discharge rate during this eruption is plotted on Figure 6, together with values of $Q_{\mathrm{cr}}$ for a $1.5 \mathrm{~km}$ long fissure and point source. The effects of more focused melting compensate for the reduced magma discharge rate, and the eruption is expected to remain explosive throughout. However, if the initial discharge rate were much lower, the focusing effect could trigger a change in the style of fissure eruptions.

\subsection{Models Applied to the Subglacial Eruption of Helgafell}

[40] Schopka et al. [2006] have provided a detailed description of the Pleistocene tindar ridge Helgafell, formed in an eruption analogous to the Gjálp eruption. The $300 \mathrm{~m}$ high edifice was emplaced on a $\sim 2 \mathrm{~km}$ long fissure beneath ice $>500 \mathrm{~m}$ thick. Pillows are notably absent, and the eruption predominately generated hydroclastic tephra. Contrasting facies associations on the northwestern and southeastern flanks of the edifice indicate pronounced differences in the eruptive mechanisms and depositional environment. Tephra on the northwestern flank is locally well stratified and was deposited by eruption-fed subaqueous density currents (corresponding to the explosive eruption scenario). The structure of the deposits indicates that meltwater drained from the eruption site to the northwest, parallel to the glacier flow direction as indicated by striae. In contrast, tephra on the southeastern flank is mostly massive, and 


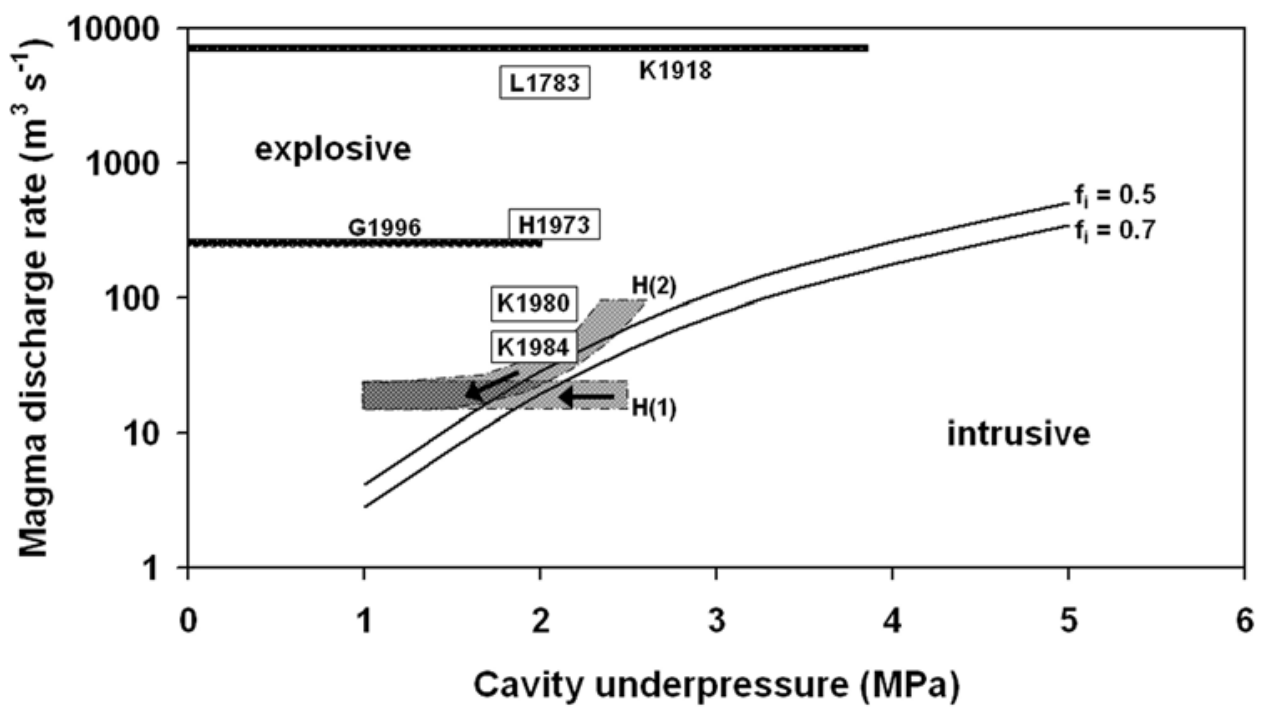

Figure 5. Critical discharge rate for eruptions on a $1.5 \mathrm{~km}$ fissure beneath $600 \mathrm{~m}$ of ice, plotted together with estimated magma discharge rates (normalized to fissure lengths of $1.5 \mathrm{~km}$ ) and cavity underpressures for historical basalt fissure eruptions in Iceland, major 20th century subglacial eruptions in Iceland and the Pleistocene tindar ridge of Helgafell. Symbols are L1783, the Laki eruption; H1973, the Heimæy eruption; K1980, Krafla, July 1980; K1984, Krafla, September 1984; G1996, the Gjálp eruption; K1918, the 1918 Katla eruption; H(1), Helgafell, with a constant magma discharge rate; and $\mathrm{H}(2)$, Helgafell, with a waning magma discharge rate. The arrows indicate the inferred change in underpressure during the Helgafell eruption, from $\sim 2.5$ to $1 \mathrm{MPa}$ [Schopka et al., 2006].

intruded by peperitic lava bodies, which were intruded within wet, unconsolidated tephra and whose abundance generally decreases upward through the edifice (intrusive eruption scenario). The water contents of glassy samples from the southeastern flank indicate that quenching pressures remained low and roughly constant, at around $1 \mathrm{MPa}$ during construction of the edifice. The fact that pressures do not correlate with elevation is thought to indicate cavity pressures were substantially lower than glaciostatic, due to drainage of meltwater from the vent area.

[41] Assuming that the eruption duration was similar to that of Gjálp (13 days), the edifice volume implies a mean magma discharge rate of $\sim 20 \mathrm{~m}^{3} \mathrm{~s}^{-1}$. The underpressure may have decreased from $\sim 2.5 \mathrm{MPa}$ close to the onset to $\sim 1 \mathrm{MPa}$ near the end of the eruption, based on the water contents in glassy samples from the succession. When this constant magma discharge rate and underpressure range is plotted on Figure 5 as H(1), it appears that the eruption was close to the explosive-intrusive transition, and would be expected to generally become more explosive as the eruption went on and the underpressure decreased - consistent with the facies associations seen. In reality, the magma discharge rate from Helgafell and similar eruptions is unlikely to have been constant throughout the eruption, and instead probably followed a similar pattern of waxing and waning flow to that described for subaerial fissure eruptions in Iceland by Wadge [1981] and Harris et al. [2000]. In this case, the initial magma discharge rate may have exceeded the average by a factor of $5-10$. This scenario has been schematically drawn on Figure 5 as $\mathrm{H}(2)$, and shows that the eruption would have been mostly explosive, but close to the explosive-intrusive transition.
Such an inference is consistent with the facies formed at Helgafell, where the eruption was predominantly explosive but some intrusion occurred, especially at the onset of the eruption.

[42] The fact that both "explosive" and "intrusive" deposits were synchronously emplaced during an eruption that may have only lasted for a few days reflects an added degree of complexity that the current models cannot account for - that of heterogeneous patterns of ice deformation. Instead of deforming symmetrically around the locus of melting, the ice at Helgafell is inferred to have principally flowed to the northwest, parallel to the regional ice flow direction [Schopka et al., 2006]. This encouraged drainage of meltwater to the northwest, maintaining open, lowpressure cavities linked to the glacier snout, while leading to closure of the ice around the southeastern part of the edifice. Horizontal ice deformation therefore appears to have tipped the balance in favor of intrusive behavior and massive deposits on one side of the edifice and deposition by meltwater on the other.

\subsection{Water Depths and Tephra Sedimentology: Basalt Versus Rhyolite}

[43] In order for hydroclastic tephra erupted at the early stages of a subglacial eruption to be well bedded, it needs to be deposited by eruption-fed density currents, with significant transport between the zones of fragmentation and deposition [e.g., White, 2000; Smellie, 2001]. Otherwise, tephra deposits will be massive and poorly sorted, with evidence for intrusion and quenching of rising magma within waterlogged tephra [e.g., Schopka et al., 2006]. In general, it is found that subglacially erupted tephra deposits directly overlying pillow lavas tend to be more poorly 


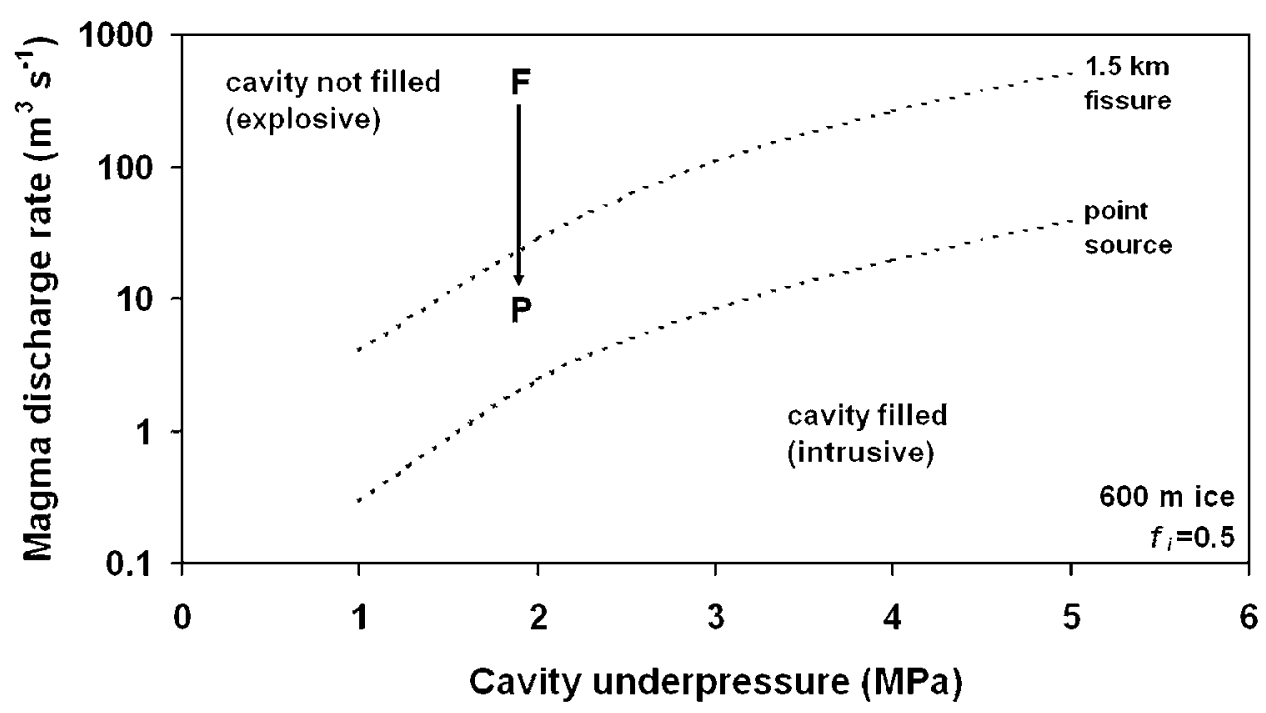

Figure 6. Simulation of the possible effects of fissure focusing on the style of an eruption beneath $600 \mathrm{~m}$ of ice with $f_{i}=0.5$. The magma discharge rate during the 1973 Heimæy eruption is indicated, which started at $500 \mathrm{~m}^{3} \mathrm{~s}^{-1}$ from a $1.5 \mathrm{~km}$ fissure $(\mathrm{F})$ and ended with $10 \mathrm{~m}^{3} \mathrm{~s}^{-1}$ from a point source $(\mathrm{P})$. Although the magma discharge rate decreased significantly, it would not have resulted in a change from an explosive to an intrusive eruption, as the melting became focused.

sorted and massive than those higher in the stratigraphy [e.g., Jones, 1970; Werner and Schmincke, 1999], although this is not always the case and many sequences have been disturbed by mass wasting associated with edifice instability and ice recession [e.g., Skilling, 1994; Smellie, 2001].

[44] Nonetheless, it is informative to consider probable water depths at the transition between pillow lava effusion and hydroclastic fragmentation during tuya-building erup- tions from a point source. Figure 7 shows the evolving depth of meltwater/steam above the growing edifice during the early phase of a simulated tuya-building eruption beneath $800 \mathrm{~m}$ of ice. A magma discharge rate of $15 \mathrm{~m}^{3} \mathrm{~s}^{-1}$ was used, which is similar to the rates for shield volcano effusion estimated by Rossi [1996]. The graph shows that the depth of meltwater above the edifice at the onset of hydroclastic fragmentation is very small, due to sluggish melting from

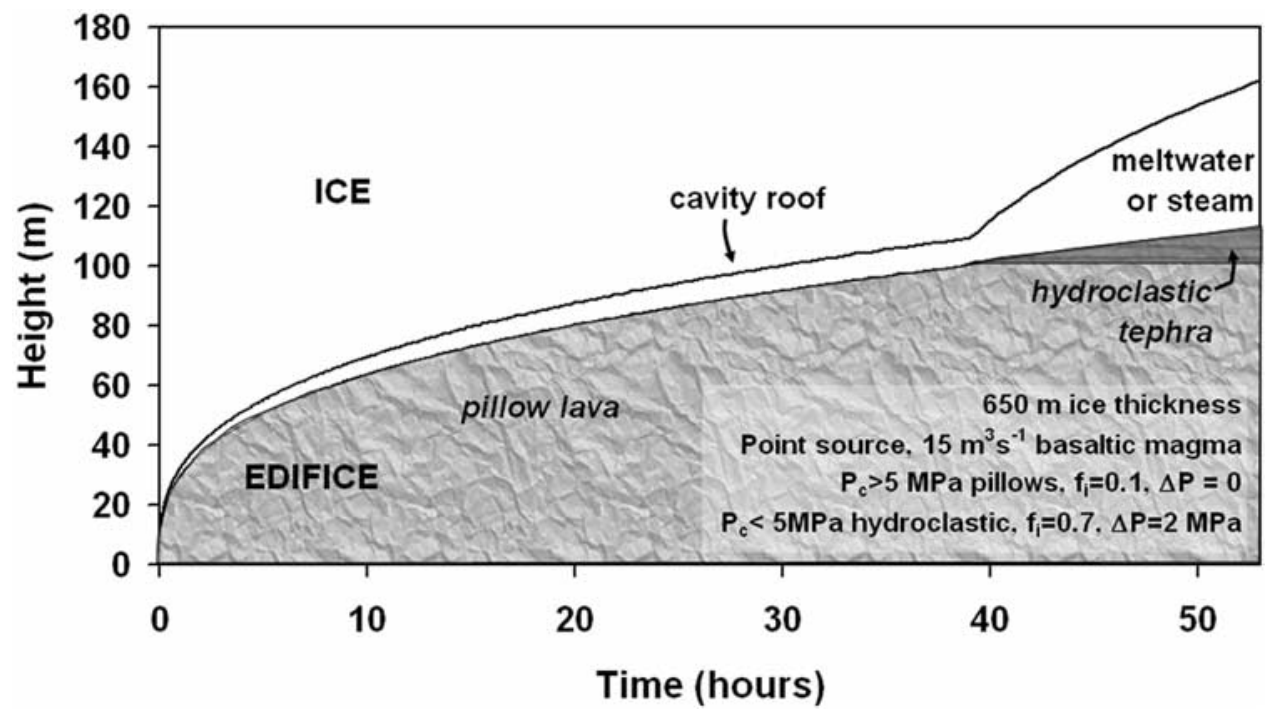

Figure 7. Simulation of the early phase of tuya construction beneath a glacier $650 \mathrm{~m}$ thick. Initially, the cavity pressure exceeds $5 \mathrm{MPa}$ and pillow lava effusion occurs within a cavity at glaciostatic pressure with almost no meltwater/steam-filled gap above the edifice. Once the cavity pressure has fallen beneath $5 \mathrm{MPa}$, a hydroclastic eruption ensues, with more rapid melting, and the height of meltwater/steam above the edifice dramatically increases. This would be expected to lead to progressively better stratification and sorting in the hydroclastic tephra as the edifice grew. 


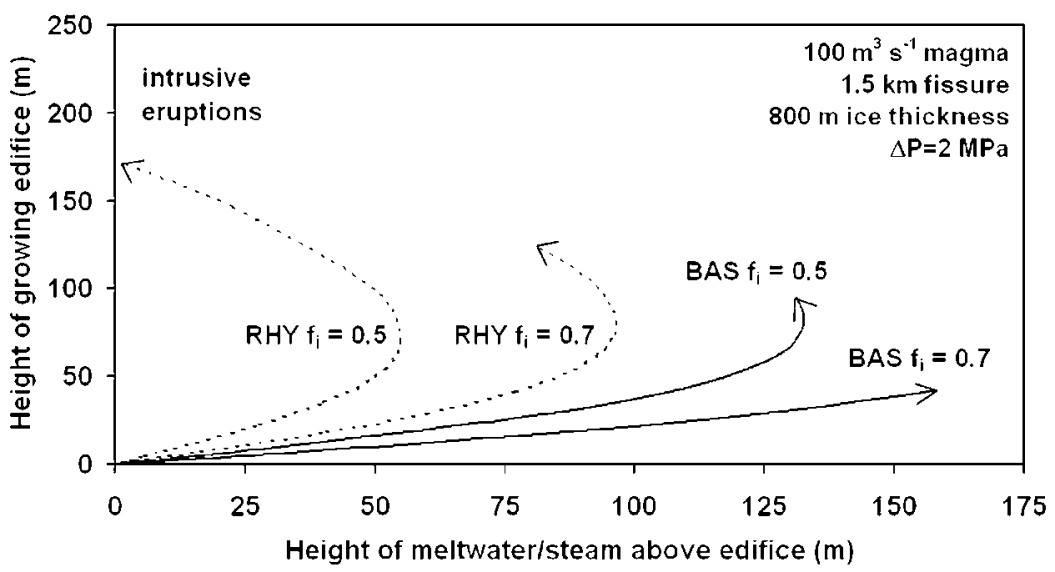

Figure 8. Comparison of the height of meltwater/steam above growing edifices during basaltic and rhyolitic eruptions at $100 \mathrm{~m}^{3} \mathrm{~s}^{-1}$ from a fissure $1.5 \mathrm{~km}$ in length beneath $800 \mathrm{~m}$ of ice and underpressure of $2 \mathrm{MPa}$. During basaltic eruptions (solid curves) the height of meltwater/steam quickly rises to over $100 \mathrm{~m}$, whereas during rhyolitic eruptions (dashed curves) the height rises less rapidly, and then falls as the edifice begins to fill the cavity. As explained in the text, this may account for differences in the sedimentology of hydroclastic deposits at basaltic and rhyolitic tuyas.

pillows, but quickly increases once the eruption becomes explosive. The evolving cavity pressure during this simulation is indicated by the arrow in Figure 2. Thus this is a potential explanation for the changes in sedimentary structure seen in some subglacial successions - although other factors, such as continuous vs. pulsatory eruptions may also play a role [e.g., Smellie and Hole, 1997; Smellie, 2001]. It must be stressed that this process is relevant to the subglacial phase of eruptions, and not to prolonged eruptions within englacial lakes [cf. Werner and Schmincke, 1999].

[45] Although they have not been as closely studied as basaltic tuyas and their fragmental deposits are less well exposed, rhyolitic tuyas appear to be significantly different from basaltic tuyas, in that the basal pedestal of hydroclastic deposits appears to be entirely massive and unstructured [Tuffen et al., 2002b]. The Höskuldsson and Sparks [1997] model can explain this in terms of pressure changes, with the inevitably positive pressure changes during rhyolitic eruptions preventing accumulation of meltwater. However, as described above, inefficient energy exchange during basaltic eruptions is likely to also lead to meltwater drainage [Guðmundsson et al., 2004]. Further evidence against a closed system comes from the field evidence for meltwater drainage during basaltic and rhyolitic subglacial eruptions [e.g., Smellie, 2001; Tuffen et al., 2001; Schopka et al., 2006; Smellie, 2006]. Additionally, it is possible for meltwater to pond during rhyolitic eruptions if the bedrock topography is not conducive to drainage [Tuffen et al., 2007a]. Therefore an attractive alternative explanation comes from the contrasting water depths that develop during basaltic and rhyolitic eruptions, due to differences in the initial magma temperature. Figure 8 shows the contrasting depth of meltwater during fissure eruptions of basaltic and rhyolitic magma, but where all other parameters are the same. Far greater water depths develop during basaltic eruptions, consistent with the greater degree of bedding and sorting seen in deposits. This is therefore an attractive alternative explanation for the contrast between rhyolitic and basaltic subglacial tephra deposits.

\section{Discussion: Limitations of the Models and Scope for Future Work}

[46] Despite the simplifications made, the models appear to successfully encapsulate the behavior of subglacial fissure eruptions in Iceland, and are consistent with the eruption mechanisms of observed and ancient basaltic fissure eruptions. However, many factors have not been taken into account, including the possible influence of horizontal ice flow highlighted by the facies associations at Helgafell.

[47] One obvious factor is the hydraulic gradient around the eruption site, and how this controls patterns of meltwater retention, accumulation and pressure. For example, at Gjálp it appears that the potential gradients controlling meltwater drainage encouraged meltwater to accumulate at the northern end of the fissure, where cavity pressures were glaciostatic and pillow lavas were emplaced, and drain away from the southern end of the fissure, favoring the establishment of lower pressure conditions and enabling explosive magmawater interaction to occur [Guðmundsson et al., 2004]. It is thus clear that the hydraulic gradient around the eruption site strongly influences the mechanisms of eruptions. This gradient is controlled by the glacier surface and bedrock topography [e.g., Björnsson, 1988; Björnsson et al., 2000; Smellie, 2006], unless the eruption occurs so close to the glacier snout that all cavities are only partly filled with meltwater and drainage is controlled by the bedrock slope alone [e.g., Syverson et al., 1994]. This added complication to what is already a complexly coupled volcano-ice system makes the application of predictive models for the mechanisms of subglacial eruptions all the more problematic. Such models would need to consider the hydrological patterns that are unique to each potential eruption site and as such would need to be 
specific to each volcano, for which the hydrological patterns are known, such as Katla volcano beneath Mýrdalsjökull [Björnsson et al., 2000].

[48] Another crucial element that has not been studied here is the potential coupling between the cavity pressure and the magma discharge rate. Coupling is known to occur over much longer timescales between glacier thicknesses and the eruption rate of basaltic magma in Iceland as a whole [e.g., Jull and McKenzie, 1996], but it may also occur during individual eruptions as the rate and direction of magma rise is controlled by the pressure gradient between the magma chamber and the surface [e.g., Pinel and Jaupart, 2000; Wilson and Head, 2002]. There is strong evidence that pressure release of $\sim 0.8 \mathrm{MPa}$ during drainage of jökulhlaups from the Grímsvötn caldera can trigger eruptions, as occurred in 1934 [Guðmundsson, 2005]. In addition, Höskuldsson et al. [2006] have suggested that jökulhlaup drainage may lead to vesiculation of pillow lavas and the reactivation of eruptions. The "transition breccia" that lies between vesicular pillow lavas and hydroclastic deposits at Kalfstindar [Jones, 1970] may also be attributed to sudden pressure decrease during meltwater drainage. Changes in cavity pressure during eruptions, which may be triggered by the propagation of a subglacial pressure wave [Jóhannesson, 2002] or simply the onset of meltwater drainage as connection is established with low-pressure subglacial cavities [e.g., Hooke, 1984], therefore clearly have the potential to drastically affect the magma discharge rate during subglacial eruptions as well as the eruption mechanism itself. Heated meltwater may also have an important effect in that it enlarges subglacial drainage pathways and encourages the establishment of low-pressure conditions [e.g., Clarke, 1982]. Studying the degassing behavior of magma in order to reconstruct confining pressures and the timescales of cooling and meltwater drainage [Höskuldsson et al., 2006; Schopka et al., 2006] is therefore an important step toward quantifying the coupling between cavity pressures, meltwater drainage and eruption mechanisms, and much work remains to be done in this area. One possible implication of this effect is that eruptions may preferentially occur in areas of high heat flux, where longlived, low-pressure subglacial cavities exist [Tuffen et al., 2002a]. This may occur at silicic volcanic centers with wellestablished geothermal fields, such as Torfajökull, Iceland or the summit crater of Mount Rainier, Washington, where an extensive low-pressure cavity system is melted by fumaroles and steam vents [Kiver and Steele, 1975]. The effect may be less relevant in basaltic systems where considerable lateral flow of magma along dikes occurs.

[49] In addition to these complications surrounding the relationship between cavity pressures and magma discharge rates, other issues that may be pertinent to the mechanisms of subglacial basaltic eruptions include (1) how magma vesicularity relates to cavity pressures and degassing during magma ascent, (2) details of how heat is transferred from magma to ice and the temperature of meltwater, and (3) the relative roles of brittle and ductile ice deformation in enlarging subglacial cavities. Nonetheless, the models presented here do appear to capture important aspects of the behavior of subglacial eruptions and to demonstrate the critical influence that cavity conditions, in particular the ability of meltwater to interact with rising magma, may exert on eruption mechanisms.

\section{Conclusions}

[50] Simplified models of edifice construction and cavity evolution during the early phases of subglacial eruptions have been presented. The major conclusions are as follows:

[51] 1. The magma discharge rate largely determines whether explosive or intrusive eruptions occur, with explosive eruptions favored by high magma discharge rates. At low magma discharge rates, closure of the ice roof onto the edifice may suppress the explosivity and lead to an intrusive style of eruption.

[52] 2. Using relevant ice thicknesses, magma discharge rates and cavity pressure regimes, the mechanisms of historical subglacial eruptions in Iceland and a Pleistocene eruption have been correctly simulated.

[53] 3. Inferred water column depths during eruptions have been used to explain why subglacial basaltic deposits are better stratified than their rhyolitic counterparts, and why hydroclastic tephra deposits directly overlying pillow lavas are generally less well stratified than those higher in the sequence.

[54] 4. Other factors such as horizontal ice deformation, coupling between cavity pressures and magma discharge rate, and the hydraulic gradient around the eruption site may also play important roles in controlling the complex feedback between eruption mechanisms and glacier response.

[55] Acknowledgments. Thanks to the Leverhulme Trust for an Early Career Research Fellowship and to Magnus Tumi Guðmundsson for inviting me to the University of Iceland in 2002 to begin developing these models. Discussions with John Smellie, Dave McGarvie, Magnus Tumi Guð̌mundsson, Jennie Gilbert, and Lionel Wilson were much appreciated, and I am indebted to Ben Edwards and John Smellie for insightful reviews that have greatly improved the paper.

\section{References}

Batiza, R., and J. D. L. White (2000), Submarine lava and hyaloclastite, in Encyclopaedia of Volcanoes, edited by H. Sigurdsson, pp. 361-382, Elsevier, New York.

Björnsson, H. (1988), Hydrology of ice caps in volcanic regions, Visindafelag Isl. Rit, 45, 139 pp.

Björnsson, H., F. Pálsson, and M. T. Guððmundsson (2000), Surface and bedrock topography of the Mýrdalsjökull ice cap, Iceland: The Katla caldera, eruption sites and routes of jökulhlaups, Joekull, 49, $29-46$.

Chapman, M. G., C. C. Allen, M. T. Guðmundsson, V. C. Gulick, S. P. Jakobsson, B. K. Lucchitta, I. P. Skilling, and R. B. Waitt (2000), Volcanism and ice interactions on Earth and Mars, in Environmental Effects on Volcanic Eruptions: From the Deep Oceans to Deep Space, edited by J. R. Zimbelman and T. K. P. Gregg, pp. 39-73, Springer, New York.

Clarke, G. K. C. (1982), Glacier outburst floods from Hazard Lake, Yukon Territory, and the problem of flood magnitude prediction, J. Glaciol., 28, $3-21$.

Cutler, P. M. (1998), Modelling the evolution of subglacial tunnels due to varying water input, J. Glaciol., 44, 485-497.

Dixon, J. E., J. R. Filiberto, J. G. Moore, and C. J. Hickson (2000), Volatiles in basaltic glasses from a subglacial volcano in Northern British Columbia: Implications for mantle volatiles and ice sheet thickness, in Ice-Volcano Interaction on Earth and Mars, edited by J. L. Smellie and M. G. Chapman, Geol. Soc. Spec. Publ., 202, 255-271.

Dobran, F., and P. Papale (1993), Magma-water interaction in closed systems and application to lava tunnels and volcanic conduits, J. Geophys. Res., 98, 14,041-14,058.

Fountain, A. G., and J. S. Walder (1998), Water flow through temperate glaciers, Rev. Geophys., 36, 299-328.

Guðmundsson, M. T. (2003), Melting of ice by magma-ice-water interactions during subglacial eruptions as an indicator of heat transfer in 
subaqueous eruptions, in Explosive Subaqueous Volcanism, Geophys. Monogr. Ser., vol. 140, edited by J. D. L. White, J. L. Smellie, and D. Clague, pp. 61-72, AGU, Washington, D. C.

Guômundsson, M. T. (2005), Subglacial volcanic activity in Iceland, in Iceland: Modern Processes, Past Environments, edited by C. J. Caseldine et al., pp. 127-151, Elsevier, New York.

Guðmundsson, M. T., and K. Cook (2004), The 1918 eruption of Katla, Iceland: Magma flow rates, ice melting rates and generation of the greatest jökulhlaup of the 20th century, paper presented at General Assembly 2004, Int. Assoc. of Volcanol. and Chem. of the Earth's Inter., Pucón, Chile.

Guð̌mundsson, M. T., F. Sigmundsson, and H. Björnsson (1997), Icevolcano interaction of the 1996 Gjálp subglacial eruption, Vatnajökull, Iceland, Nature, 389, 954-957.

Guðmundsson, M. T., F. Pálsson, H. Björnsson, and P. Högnadóttir (2002), The hyaloclastite ridge formed in the subglacial 1996 eruption in Gjálp, Vatnajökull, Iceland: Present day shape and future preservation, in IceVolcano Interaction on Earth and Mars, edited by J. L. Smellie and M. G. Chapman, Geol. Soc. Spec. Publ., 202, 319-335.

Guð̌mundsson, M. T., F. Sigmundsson, H. Björnsson, and P. Högnadóttir (2004), The 1996 eruption at Gjálp, Vatnajökull ice cap, Iceland: Course of events, efficiency of heat transfer, ice deformation and subglacial water pressure, Bull. Volcanol., 66, 46-65.

Harris, A. J. L., J. B. Murray, S. E. Aries, M. A. Davies, L. P. Flynn, M. J. Wooster, R. Wright, and D. A. Rothery (2000), Effusion rate trends at Etna and Krafla and their implications for eruptive mechanisms, J. Volcanol. Geotherm. Res., 102, 237-269.

Hooke, R. L. (1984), On the role of mechanical energy in maintaining subglacial water conduits at atmospheric pressure, J. Glaciol., 30, $180-187$.

Hooke, R. L., T. Laumann, and J. Kohler (1990), Subglacial water pressures and the shape of subglacial conduits, J. Glaciol., 36, 67-71.

Höskuldsson, A., and R. S. J. Sparks (1997), Thermodynamics and fluid dynamics of effusive subglacial eruptions, Bull. Volcanol., 59, 219-230.

Höskuldsson, A., R. S. J. Sparks, and M. R. Carroll (2006), Constraints on the dynamics of subglacial basalt eruptions from geological and geochemical observations at Kverkfjöll, NE-Iceland, Bull. Volcanol., 68 , $689-701$.

Jóhannesson, T. (2002), Propagation of a subglacial flood wave during the initiation of a jökulhlaup, Hydrol. Sci. J., 47, 417-434.

Jones, J. G. (1969), Intraglacial volcanoes of the Laugarvatn region, southwest Iceland I, Q. J. Geol. Soc. London, 124, 197-211.

Jones, J. G. (1970), Intraglacial volcanoes of the Laugarvatn region, southwest Iceland II, J. Geol., 78, 127-140.

Jönsson, S., N. Adam, and H. Björnsson (1998), Effects of subglacial geothermal activity observed by satellite radar interferometry, Geophys. Res. Lett., 25, 1059-1062.

Jull, M., and D. McKenzie (1996), The effect of deglaciation on mantle melting beneath Iceland, J. Geophys. Res., 101, 21,815-21,828.

Kiver, E. P., and W. K. Steele (1975), Firn caves in the volcanic craters of Mount Rainier, Washington, NSS Bull., 37, 45-55.

Mathews, W. H. (1947), Tuyas, flat-topped volcanoes in northern British Columbia, Am. J. Sci., 245, 560-570.

Mizuno, Y. (1998), Effect of hydrostatic confining pressure on the failure mode and compressive strength of polycrystalline ice, J. Phys. Chem. B, $102,376-381$.

Moore, J. G., and L. C. Calk (1991), Degassing and differentiation in subglacial volcanoes, Iceland, J. Volcanol. Geotherm. Res., 46, 157180 .

Moore, J. G., and J.-G. Schilling (1973), Vesicles, water and sulfur in Reykjanes Ridge basalts, Contrib. Mineral. Petrol., 41, 105-118.

Moore, J. G., C. J. Hickson, and L. C. Calk (1995), Tholeiitic-alkalic transition at subglacial volcanoes, Tuya region, British Columbia, Canada, J. Geophys. Res., 100, 24,577-24,592.

Nye, J. F. (1953), The flow law of ice from measurements in glacier tunnels, laboratory experiments and the Jungfraufirn borehole experiment, Proc. R. Soc. London, Ser. A, 219, 477-489.

Pinel, V., and C. Jaupart (2000), The effect of edifice load on magma ascent beneath a volcano, Philos. Trans. R. Soc. London, Ser. A, 358, $1515-$ 1532.

Rossi, M. J. (1996), Morphology and mechanism of eruption of postglacial shield volcanoes in Iceland, Bull. Volcanol., 57, 530-540.

Sæmundsson, K. (1979), Outline of the geology of Iceland, Joekull, 29, $7-$ 28.

Schopka, H. H., M. T. Guð̊mundsson, and H. Tuffen (2006), The formation of Helgafell, SW-Iceland, a monogenetic subglacial hyaloclastite ridge: Sedimentology, hydrology and ice-volcano interaction, J. Volcanol. Geophys. Res., 152, 359-377.

Skilling, I. P. (1994), Evolution of an englacial volcano: Brown Bluff, Antarctica, Bull. Volcanol., 56, 573-591.
Smellie, J. L. (2000), Subglacial eruptions, in Encyclopaedia of Volcanoes, edited by H. Sigurdsson, pp. 403-418, Elsevier, New York.

Smellie, J. L. (2001), Lithofacies architecture and construction of volcanoes in englacial lakes: Icefall Nunatak, Mount Murphy, eastern Marie Byrd Land, Antarctica, in Volcaniclastic Sedimentation in Lacustrine Settings, edited by J. D. L. White and N. R. Riggs, Int. Assoc. Sedimentol., Spec. Publ., 30, 73-98.

Smellie, J. L. (2006), The relative importance of supraglacial versus subglacial meltwater escape in basaltic subglacial tuya eruptions: An important unresolved conundrum, Earth Sci. Rev., 74, 241-268.

Smellie, J. L., and M. J. Hole (1997), Products and processes in PlioceneRecent, subaqueous to emergent volcanism in the Antarctic Peninsula: Examples of englacial Surtseyan volcano construction, Bull. Volcanol., $58,628-646$

Smellie, J. L., and I. P. Skilling (1994), Products of subglacial volcanic eruptions under different ice thicknesses: 2 examples from Antarctica, Sediment. Geol., 91, 115-129.

Syverson, K. M., S. J. Gaffield, and D. M. Mickelson (1994), Comparison of esker morphology and sedimentology with former ice-surface topography, Burroughs Glacier, Alaska, Geol. Soc. Am. Bull., 106, 11301142.

Thorarinsson, S., S. Steinthorsson, T. Einarsson, H. Kristmansson, and N. Oskarsson (1973), Eruption on Heimæy, Iceland, Nature, 241, $372-375$.

Thordarson, T., and S. Self (1993), The Laki (Skaftar-fires) and Grímsvötn eruptions in 1783-1785, Bull. Volcanol., 55, 233-263.

Tuffen, H. (2001), Subglacial rhyolite volcanism at Torfajökull, Iceland, Ph.D. thesis, 381 pp., Open Univ., Milton Keynes, U. K.

Tuffen, H., J. S. Gilbert, and D. W. McGarvie (2001), Products of an effusive subglacial rhyolite eruption: Bláhnúkur, Torfajökull, Iceland, Bull. Volcanol., 63, 179-190.

Tuffen, H., H. Pinkerton, J. S. Gilbert, and D. W. McGarvie (2002a), Melting of the glacier base during a small-volume subglacial rhyolite eruption: Evidence from Bláhnúkur, Iceland, Sediment. Geol., 149, $183-198$.

Tuffen, H., D. W. McGarvie, J. S. Gilbert, and H. Pinkerton (2002b), Physical volcanology of a subglacial-to-emergent rhyolitic tuya at Rauðufossafjöll, Torfajökull, Iceland, in Ice-Volcano Interaction on Earth and Mars, edited by J. L. Smellie and M. G. Chapman, Geol. Soc. Spec. Publ., 202, 213-236.

Tuffen, H., D. W. McGarvie, H. Pinkerton, J. S. Gilbert, and R. A. Brooker (2007a), A mixed explosive-intrusive subglacial rhyolite eruption at Dalakvísl, Rauðufossafjöll, Iceland, Bull. Volcanol., in press.

Tuffen, H., J. S. Gilbert, and D. W. McGarvie (2007b), Will subglacial rhyolite eruptions be explosive or intrusive? Evidence from analytical models, Ann. Glaciol., in press.

Wadge, G. (1981), The variation of magma discharge during basaltic eruptions, J. Volcanol. Geotherm. Res., 11, 139-168.

Werner, R., and H.-U. Schmincke (1999), Englacial vs lacustrine origin of volcanic table mountains: Evidence from Iceland, Bull. Volcanol., 60, $335-354$

Werner, R., H.-U. Schmincke, and G. Sigvaldasson (1996), A new model for the evolution of table mountains: Volcanological and petrological evidence from Herðubreid and Herðubreidartogl volcanoes (Iceland), Geol. Rundsch., 85, 390-397.

White, J. D. L. (1996), Impure coolants and interaction dynamics of phreatomagmatic eruptions, J. Volcanol. Geotherm. Res., 74, 155-170.

White, J. D. L. (2000), Subaqueous eruption-fed density currents and their deposits, Precambrian Res., 101, 87-109.

Wilson, L., and J. W. Head (2002), Heat transfer and melting in subglacial basaltic volcanic eruptions: Implications for volcanic deposit morphology and meltwater volumes, in Ice-Volcano Interaction on Earth and Mars, edited by J. L. Smellie and M. G. Chapman, Geol. Soc. Spec. Publ., 202, $5-26$.

Wohletz, K. H. (1983), Mechanisms of hydrovolcanic pyroclast formation: Grain-size, scanning electron-microscopy, and experimental studies, J. Volcanol. Geotherm. Res., 17, 31-63.

Wylie, J. J., et al. (1999), Flow localization in fissure eruptions, Bull. Volcanol., 60, 432-440.

Zimanowski, B., and R. Büttner (2003), Phreatomagmatic explosions in subaqueous volcanism, in Explosive Subaqueous Volcanism, Geophys. Monogr. Ser, vol. 140, edited by J. D. L. White, J. L. Smellie, and D. Clague, pp. 51-60, AGU, Washington, D. C.

Zimanowski, B., R. Büttner, and V. Lorenz (1997), Premixing of magma and water in MFCI experiments, Bull. Volcanol., 58, 491-495.

H. Tuffen, Department of Environmental Science, Lancaster University, Bailrigg, Lancaster LA1 4YQ, UK. (h.tuffen@lancaster.ac.uk) 